\title{
Assessment of Variation of Winter Severity Types in the Siedlce Area
}

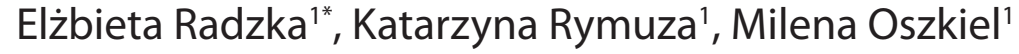 \\ 1 Faculty of Natural Sciences, Siedlce University of Natural Sciences, ul. Prusa 14, 08-110 Siedlce, Poland \\ * Corresponding author's e-mail: elzbieta.radzka@uph.edu.pl
}

\begin{abstract}
The objective of the work was to describe the thermal and snow conditions in the winter period in the Siedlce area. The average daily air temperatures were used in addition to numbers of days with a snow cover of at least $1 \mathrm{~cm}$ for the years 2000-2016 obtained from the Meteorological Station in Siedlce. Dates of the beginning and end of the winter season were determined. The average temperature of the winter season was determined in addition to the degree of winter severity, according to Oskin. The average, minimum and maximum values of parameters were calculated. The probability of an occurrence of individual types of winter severity was determined. Next, principal component analysis and cluster analysis were applied, the latter to the group years in terms of the days with a given type of weather in winter. It was found that - on average - the thermal winter began on 5 December and ended on 6th March. The winter was found to have lasted for 66 days. From year to year, there was observed an increase in the average number of days with mild weather. The greatest decline was found for the days with the weather typical of slightly severe and moderately severe winter. The last study years had the highest average number of days with weather typical of mild, slightly severe and moderately severe winter, and the lowest number of the days with weather typical of severe, very severe, unusually severe and extremely severe winter.
\end{abstract}

Keywords: indicator of weather severity, winter, variation, Siedlce

\section{INTRODUCTION AND WORK OBJECTIVE}

Over the last thirty years, a very distinct increase in the average air temperature has been observed. Winters have become milder and the majority of them have been snowless, autumns have been cooler than springs and summers have become hot. A radical increase in the warming rate has been observed in the last twenty years of the 20th century and the beginning of the 21st century (Kożuchowski and Żmudzka 2001). Kożuchowski (2004) claims that warming is much more obvious in the first half of the calendar year. Winters are becoming milder and early spring occurs earlier. Many researchers have studied the 'frostiness' or 'severity' of winter by applying various indicators and assessment criteria. The published works include the paper by Bednarek et al. (1979) for the Lublin area, by Olba-Zięty and Grabowski (2007) for the Biebrza River Valley, Nowosad (1998) and Janasz (2000) for Lublin, and Majewski et al. (2011) for
Warszawa. There are works for Poland, Polish regions or localities presenting thermal description of winters (Piotrowicz 2002-2003) or snow cover only (Chrzanowski 1986, Falarz 2007, Nowosad and Bartoszek 2007, Czarnecka 2012). The values of average daily, minimum and maximum air temperature were used for calculations. Paczos (1985) divided the characteristics of winter severity into three groups. The first group includes the works which used the sums of average daily temperatures below $0^{\circ} \mathrm{C}$ or the sums of maximum and minimum temperature above and below $0^{\circ} \mathrm{C}$ for the assessment of thermal conditions. However, the classification criteria based on this method are not uniform. The second group consists of the methods based on an average air temperature during winters and its deviation from the longterm mean. The following months are taken into account in the works employing these methods: November-March, December-March, DecemberFebruary and even January-February. The third group focuses on the works the authors of which 
make use of mathematical formulas demonstrating relationships of 'the indicator of winter severity'. Classification of winters is not an easy task, due to the weather changeability and contrasts in our climate. In Poland, the meteorological conditions during winters are predominantly affected by the Icelandic low, the Azores high as well as the Russian high. The result of it is an in-season and long-term variation of winters. The full description of annual, monthly or seasonal climatic conditions requires an objective assessment of the thermal conditions or, to be more precise, determination of the relationship between the thermal conditions in a given part of the year and a longterm mean (Warakomski 1989/90). The beginning of winter is assumed to be the date when the average daily air temperature is $0^{\circ} \mathrm{C}$ or less (Górska-Zajączkowska and Wójtowicz 2011). In Poland, the warmest region in winter is the coastal belt in which the average temperature is $0.0^{\circ} \mathrm{C}$. In the remainder of the country, the average temperature in this season is negative (Filipiak 2004). Morawska-Horawska (1991) claims that there are also heat waves or cold spells. On average, there are 3 to 5 heat waves and 2-4 cold spells during the year in Poland. The indicators of snowfall intensity and thermal severity are on the decline. The number of days with the snow cover with the thickness greater than 5, 10 , and $20 \mathrm{~cm}$ is falling, and the number of days with the snow cover, regardless of its thickness, is increasing (Radzka 2015).

\section{MATERIALS AND METHODS}

The work presents results of observations from the Siedlce Meteorological Station for the years 2000-2016. The following data were used: average daily air temperature, average daily air humidity, and number of days when snow cover was recorded in individual months.

The dates of the beginning and end of thermal winter were determined based on the formulas suggested by R. Gumiński. Determination of the beginning and end of each season in a given year may be difficult because temperature changes day to day in an irregular pattern and, in the case of thermal winter, raises above and falls below $0.0^{\circ} \mathrm{C}$ several times during 24 hours. The thermal seasons of the year are determined based on longterm data. Relying on average values of longterm daily temperatures for consecutive days of the year seems to be the most accurate. As not all stations have such information, the dates when the temperatures cross the threshold values are calculated in a simplified manner based on the average monthly temperature and using the formulas by R. Gumiński. He takes into account the following assumptions:

- the average monthly temperature falls on the 15th day of the month,

- each month has 30 days,

- a change in temperature (increase, decline) from month to month takes place steadily.

The following formulas were used for calculations:

$$
x_{1}=\frac{t_{p}-t_{1}}{t_{2}-t_{1}} 30 x_{2}=\frac{t_{1}-t_{p}}{t_{1}-t_{2}} 30
$$

where: $t_{p}$ - threshold temperature,

$t_{1}$ - average air temperature in the month preceding an occurrence of the threshold temparature,

$t_{2}$ - average air temperature in the month following an occurrence of the threshold temperature, $X_{1}, X_{2}-$ number of days.

The first formula was used to determine early spring, which marks the end of winter, whereas the second one to determine the beginning of winter. The formulas were utilised to determine the dates of the beginning and end of seasons in consecutive years of the studied 16-year period, using threshold temperatures for individual seasons of the years as $t_{p}$, and average monthly temperatures in each studied year as $t_{1}$ and $t_{2}$. The calculated number of days was added to the 15th day of the preceding month. When the sought value is higher than 15 , one has to pay attention to the actual number of days in this month while adding it. This is the way to obtain the sought date which will be the beginning or end of the next season of the year. The number of days and the average air temperature of thermal winter were calculated. Seven types of weather can be distinguished based on the indicator of climate severity which reflects weather severity in the winter season. The weather severity indicator, drawn up by Oskin is very important in the assessment of bioclimatic conditions of the winter period for recreational purposes. In not only takes into account the wind speed and air temperature but also the coefficients describing air humidity $(\mathrm{F})$, absolute altitude of the locality (Hk) and daily amplitude of air temperature (At). 
The following formulas were used to assess weather severity:

$$
\begin{gathered}
S O=(1-0.06 \cdot t) \cdot(1+0.20 \cdot v) \cdot \\
\cdot(1+0.0006 \cdot H k) \cdot F \cdot A t
\end{gathered}
$$

where: $S O$ - climate severity indicator (Oskin's),

$t$-air temperature,

$v$ - wind speed,

$H k^{-}$absolute altitude of the locality,

$F$ - coefficient reflecting air humidity,

At - coefficient reflecting daily amplitude of air temperature.

According to Oskin, there are no marked changes in the functioning of the human heart and airways up to 400 metres above sea level. In the localities which are situated below this altitude, the value $\mathrm{Hk}$ is assumed to be 0 . If relative air humidity is higher than $60 \%$, the value $\mathrm{F}=0.90$. When humidity is higher, $\mathrm{F}$ is calculated using the following formula:

$$
F=0.005 \cdot R H+0.645
$$

where: $F$ - coefficient describing air humidity, $R H$ - relative air humidity.

When daily air temperature amplitude (dt) is up to $4^{\circ} \mathrm{C}$, the coefficient At equals 0.85 . If $\mathrm{dt}$ is higher than $18^{\circ} \mathrm{C}$, At is 1.25 . In the remaining cases, the daily air temperature amplitude is calculated in the following way:

$$
A t=0.025 \cdot d t+0.7998
$$

where: $A t-$ coefficient describing the daily amplitude of air temperature,

$d t$ - daily amplitude of air temperature higher than $4^{\circ} \mathrm{C}$ and lower than $18^{\circ} \mathrm{C}$,

In order to assess the weather severity according to Oskin, appropriate $\mathrm{SO}$ values have to be assumed:
SO

1 and less

more than 1 to 2

more than 2 to 3

more than 3 to 4

more than 4 to 5

more than 5 to 7

more than 7

\section{Weather severity of the winter period:}

mild weather

slightly severe eather

moderately severe weather

severe weather

very severe weather

unusually severe weather

extremely severe weather
In the analysis, the following basic statistical measures were calculated: mean, minimum, maximum and standard deviation. In order to exam- ine the changes in phenomena (types of weather) over the years 2000-2016, dynamics indicators were used: chain indices, average rate of increase, fixed-base indices (the year 2000 was assumed to be the base year) (Sobczyk, 2007).

Fixed-base indices with the constant base $(2000=100 \%)$ and chain indices (calculated year to year) were computed according to the formula:

$$
I=\frac{y_{1}}{y_{0}} \times 100 \%
$$

where: $I$-dynamics index,

$y_{1}-$ value of the phenomenon in the study period,

$y_{0}-$ value of the phenomenon in the year assumed as the basis.

Chain indices were used to calculate the average rate of changes:

$$
\bar{T}=\left(\bar{y}_{g}-100\right)
$$

where: $\quad \bar{T}$ - average rate of changes,

$$
\bar{y}_{g} \text { - geometrical mean. }
$$

In the second phase, principal component analysis (PCA) was used. PCA includes the total variance of variables and explains maximum variation in the dataset. Moreover, principal components are a function of the primary variable and are always independent. The number of principal components included in further analysis was determined using the Kaiser criterion according to which components the eigenvalues of which is higher than 1 are analysed (Morrison 1990, Stanisz 2009). Next, the cluster analysis was applied to group the studied years according to the number of days characterised by a given weather type in winter. The grouping was performed following the method by Ward and using the Euclidean distance. In order to determine the cut-off point of the dendrogram, the Mojena rule was used (Stanisz 2007).

\section{ANALYSIS OF RESULTS}

In 2000-2016, the thermal winter in the Siedlce area lasted 66 day, on average (Table 1). It began on 5th December and ended on 6th March, on average. The average air temperature of the thermal winter was $-2.1^{\circ} \mathrm{C}$, and the number of days with snow cover per year was 37 days on average. The earliest beginning of the analysed season was on 
Table 1. Average, minimum and maximum dates as well as the standard deviation of the dates of the beginning and end of thermal winter, number of days, average air temperature and number of days with snow cover of thermal winter in the Siedlce area

\begin{tabular}{|c|c|c|c|c|c|}
\hline Parameter & The begining date & The end date & Number of days & $\begin{array}{c}\text { Average air temp. } \\
\text { of thermal winter } \\
\left({ }^{\circ} \mathrm{C}\right)\end{array}$ & $\begin{array}{c}\text { Number of days } \\
\text { with snow cover }\end{array}$ \\
\hline Average & 5 Dec. & 06 Mar. & 66 & -2.1 & 37 \\
\hline Min. & 26 Nov. & 22 Jan. & 24 & -6.0 & 8 \\
\hline Max. & 31 Jan. & 08 Apr. & 96 & 0.0 & 68 \\
\hline Standard deviation & 17 Apr. & 5 Jan. & 20 & 1.9 & 17 \\
\hline
\end{tabular}

26th November, and the latest one on 31st January. The earliest recorded date of the end of winter was 22nd January and the latest one was 8th April.

Table 2 presents a comparison of the number of days characterised by a given type of weather in winter to the period directly preceding the study period. In 2006-2009, the number of days with the weather typical of mild winter did not vary. An increase in the number of days with such weather type compared with the preceding year was observed in 2002 (by 300\%), 2004 (by 100\%), 2010 (by 400\%) as well as 2013 and 2014. From year to year, the number of days when the weather was typical of mild winter increased by $9.7 \%$, on average. A fluctuation in the number of days with the remaining weather types was observed in the study period. In the long-term period, there was a decline in the number of the days with the weather typical of severe winter, on average, by $23.77 \%$ every year, whereas for the days with moderately severe weather, the decline was $18.18 \%$, for the days with unusually severe weather by almost $7 \%$. In contrast, an increase in the number of days with the weather typical of severe, very severe and extremely severe weather was observed, which amounted to 5.16, 4.48 and $7.85 \%$, respectively. The year 2013 was of particular interest as the number of days with weather typical of extremely severe winter increased by 900\% compared with 2012 .

Table 3 contains the number of days with a given weather type in winter compared with 2000 (the base year). From 2013 to 2016, there was an increase in the number of days with weather typical of mild winter. An increase in the number of days with weather typical of slightly severe winter

Table 2. Analysis of dynamics of changes in the number of days with a given weather type during winter compared with the period directly preceding the study period

\begin{tabular}{|c|c|c|c|c|c|c|c|}
\hline Years & Mild & Slightly severe & $\begin{array}{c}\text { Moderately } \\
\text { severe }\end{array}$ & Severe & Very severe & $\begin{array}{c}\text { Unusually } \\
\text { severe }\end{array}$ & $\begin{array}{c}\text { Extremely } \\
\text { severe }\end{array}$ \\
\hline 2000 & & & & & & & \\
\hline 2001 & 100 & 44 & 78 & 111 & 115 & 208 & 133 \\
\hline 2002 & 400 & 182 & 107 & 95 & 87 & 67 & 100 \\
\hline 2003 & 25 & 105 & 117 & 76 & 140 & 72 & 75 \\
\hline 2004 & 200 & 71 & 55 & 145 & 129 & 177 & 100 \\
\hline 2005 & 50 & 80 & 103 & 107 & 125 & 91 & 133 \\
\hline 2006 & 100 & 150 & 147 & 82 & 64 & 76 & 75 \\
\hline 2007 & 100 & 83 & 104 & 70 & 72 & 81 & 200 \\
\hline 2008 & 100 & 87 & 104 & 181 & 119 & 69 & 100 \\
\hline 2009 & 100 & 123 & 118 & 81 & 80 & 133 & 67 \\
\hline 2010 & 500 & 294 & 57 & 82 & 75 & 100 & 125 \\
\hline 2011 & 20 & 28 & 156 & 158 & 160 & 67 & 40 \\
\hline 2012 & 100 & 185 & 89 & 82 & 71 & 275 & 50 \\
\hline 2013 & 300 & 58 & 104 & 110 & 147 & 68 & 100 \\
\hline 2014 & 200 & 236 & 104 & 84 & 32 & 33 & 1000 \\
\hline 2015 & 67 & 100 & 133 & 84 & 125 & 80 & 10 \\
\hline 2016 & 125 & 88 & 81 & 129 & 170 & 125 & 600 \\
\hline $\begin{array}{c}\text { Average } \\
\text { rate of } \\
\text { changes }\end{array}$ & 9.7 & -23.77 & -18.18 & 5.16 & 4.48 & -6.89 & 7.85 \\
\hline
\end{tabular}


Table. 3. Analysis of the dynamics of changes in the number of days with a given weather type during winter compared with 2000

\begin{tabular}{|c|c|c|c|c|c|c|c|}
\hline Years & Mild & $\begin{array}{c}\text { Slightly } \\
\text { severe }\end{array}$ & $\begin{array}{c}\text { Moderately } \\
\text { severe }\end{array}$ & Severe & $\begin{array}{c}\text { Very } \\
\text { severe }\end{array}$ & $\begin{array}{c}\text { Unusually } \\
\text { severe }\end{array}$ & $\begin{array}{c}\text { Extremely } \\
\text { severe }\end{array}$ \\
\hline 2000 & & & & & & & \\
\hline 2001 & 100 & 44 & 78 & 111 & 115 & 208 & 133 \\
\hline 2002 & 400 & 80 & 83 & 106 & 100 & 138 & 133 \\
\hline 2003 & 100 & 84 & 97 & 81 & 140 & 100 & 100 \\
\hline 2004 & 200 & 60 & 53 & 117 & 180 & 177 & 100 \\
\hline 2005 & 100 & 48 & 55 & 125 & 225 & 162 & 133 \\
\hline 2006 & 100 & 72 & 81 & 103 & 145 & 123 & 100 \\
\hline 2007 & 100 & 60 & 84 & 72 & 105 & 100 & 200 \\
\hline 2008 & 100 & 52 & 88 & 131 & 125 & 69 & 200 \\
\hline 2009 & 100 & 64 & 103 & 106 & 100 & 92 & 133 \\
\hline 2010 & 500 & 188 & 59 & 86 & 75 & 92 & 167 \\
\hline 2011 & 100 & 52 & 91 & 136 & 120 & 62 & 67 \\
\hline 2012 & 100 & 96 & 81 & 111 & 85 & 169 & 33 \\
\hline 2013 & 300 & 56 & 84 & 122 & 125 & 115 & 33 \\
\hline 2014 & 600 & 132 & 88 & 103 & 40 & 38 & 333 \\
\hline 2015 & 400 & 132 & 117 & 86 & 50 & 31 & 33 \\
\hline 2016 & 500 & 116 & 95 & 111 & 85 & 38 & 200 \\
\hline
\end{tabular}

was recorded in 2010 and 2014-2016. Compared with 2000 , the number of days with weather typical of moderately severe winter increased by $3 \%$ and $17 \%$ in 2009 and 2015, respectively. In general (during 15 years), there was an increase in the number of days with weather typical of severe, very severe and extremely severe winter. The fact that the number of days with weather typical of very severe and unusually severe winter declined in the last three years is of interest.

The principal component analysis demonstrated that the number of days with a given weather type in winter was in $77 \%$ affected by the study years. They were the most influenced by the number of days with the weather typical of very severe, slightly severe and extremely severe winter, as indicated by values of correlation coefficients pertaining to the first principal component (PC1) which were -0.888 ; 0.822 and -0.759 , re- spectively. The second principal component carried the information on the number of days with weather typical of moderately severe and mild winter. The reciprocal multi-trait associations indicate that the years when there were more days with weather typical of slightly severe winter had less days with the weather typical of very severe and extremely severe winter. In turn, in years with more days characterised by the weather typical of moderately severe winter, there were less days with a mild weather type (table 4).

On the basis of the cluster analysis, three groups of years were formed, characterised by similar characteristics of winter severity. The first group included 11 years, the second group was made up of the years 2004 and 2005 and the third group consisted of 2010, 2014, 2015 and 2016 (Fig. 1). The years in group 3 had the highest average number of days with weather typical of mild,

Table 4. Factor loads, eigenvalues and proportion of the first two principal components in the total variance

\begin{tabular}{|l|c|c|}
\hline \multicolumn{1}{|c|}{ Traits } & PC1 & PC2 \\
\hline$X_{1}-$ number of days with mild winter & 0.735 & -0.410 \\
\hline$X_{2}-$ number of days with slightly severe winter & 0.822 & -0.324 \\
\hline$X_{3}-$ number of days with moderately severe winter & 0.528 & 0.809 \\
\hline$X_{4}-$ number of days with severe winter & -0.553 & 0.099 \\
\hline$X_{5}-$ number of days with very severe winter & -0.888 & -0.126 \\
\hline$X_{6}-$ number of days with extremely severe winter & -0.759 & -0.303 \\
\hline Eigenvalue principal components & 3.2 & 1.4 \\
\hline Explainded proportion of total variance (\%) & 57.2 & 20.1 \\
\hline Comulative proportion of total variance (\%) & 57.2 & 77.3 \\
\hline
\end{tabular}




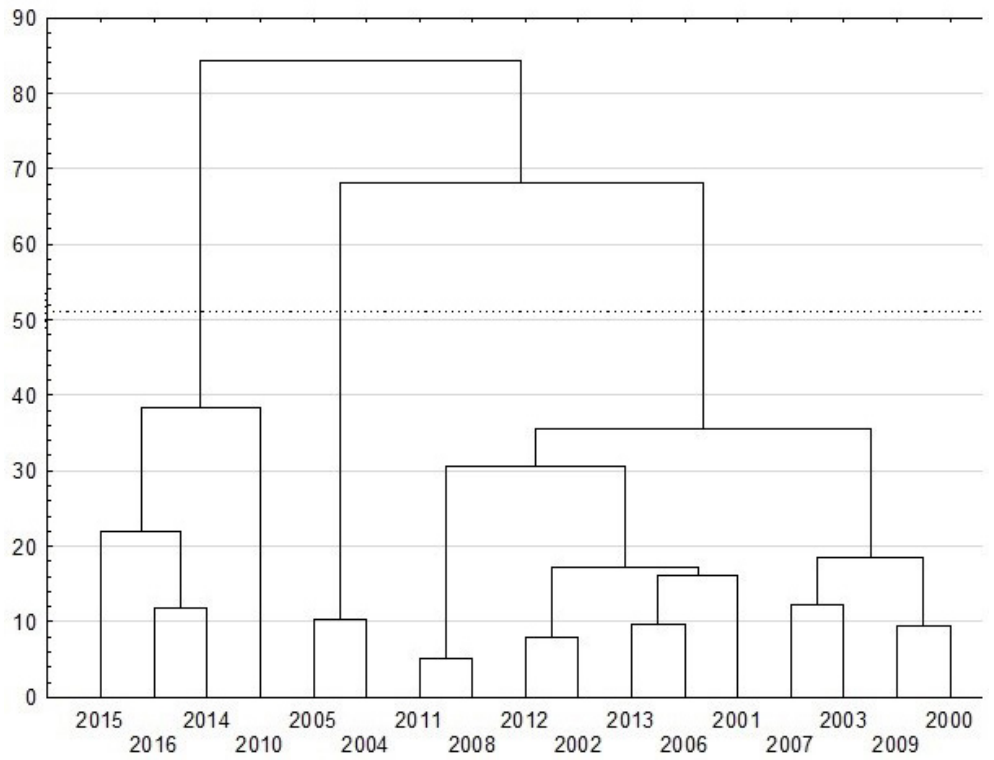

Fig. 1. Dendrogram of grouping of years in terms of according to weather types in winter

Table 5. Average numbers of days with a given weather type for groups formed by means of the cluster analysis

\begin{tabular}{|c|c|c|c|c|c|c|c|}
\hline Group & Mild & $\begin{array}{c}\text { Slightly } \\
\text { severe }\end{array}$ & Moderately severe & Severe & Very severe & $\begin{array}{c}\text { Unusually } \\
\text { severe }\end{array}$ & $\begin{array}{c}\text { Extremely } \\
\text { severe }\end{array}$ \\
\hline group 1 & 1.45 & 17.27 & 51.18 & 38.55 & 22.91 & 15.09 & 3.36 \\
\hline group 2 & 1.50 & 13.50 & 31.50 & 43.50 & 40.50 & 22.00 & 3.50 \\
\hline group 3 & 5.00 & 35.50 & 52.00 & 34.75 & 12.50 & 6.50 & 5.50 \\
\hline
\end{tabular}

slightly severe, and moderately severe winter, and the lowest average number of days with weather typical of severe, very severe, unusually severe and extremely severe winter. The years 2004 and 2005 , which formed the group 2, had the lowest average number of days with weather typical of slightly severe and moderately severe winter, and the highest average number of days with weather typical of severe, very severe, unusually severe and extremely severe winter (Table 5).

\section{CONCLUSIONS}

1. The thermal winter in the Siedlce area in 2000-2016 began on 5th December and ended on 6th March, on average. The winter was found to have lasted for 66 days. The average temperature of the thermal winter was $-2.1^{\circ} \mathrm{C}$. The number of days with snow cover through the year averaged 37 days.

2. The analysis of the dynamics of changes in the number of days with a given weather type in winter demonstrated that from year to year, there was an average increase in the number of days with mild weather (by $9.70 \%$ ). The greatest decline was found for the days with weather typical of slightly severe and moderately severe winter (by $23.77 \%$ and $18.18 \%$, respectively).

3. Compared to the base year 2000 , there was an increase in the number of days with the weather typical of severe, very severe and extremely severe winter. It was found that the number of days with the weather typical of very severe and unusually severe winter declined during the period of the last 3 years.

4. The cluster analysis yielded three groups of years characterised by similar traits of winter severity. The first group included 11 years, the second group was composed of the year 2004 and 2005, and the third group was formed by 2010, 2014, 2015 and 2016. The last study years had the highest number of days with the weather typical of mild, slightly severe and moderately severe winter, and the lowest number of the days with the weather typical of severe, very severe, unusually severe and extremely severe winter. 


\section{REFERENCES}

1. Bednarek H., Kołodziej J., Liniewicz H., 1979. Charakterystyka termiki powietrza i szaty śnieżnej w chłodnej porze roku na Lubelszczyźnie (1950/51-1969/70). Folia Soc. Sci. Lubl. 21. Geografia. 2. 75-81.

2. Chrzanowski J., 1986. Pokrywa śnieżna w Polsce i klasyfikacja jej grubości. Wiad. Inst. Meteorol. Gosp. Wod. 9/30. 2. 11-29.

3. Czarnecka M., 2012. Częstość występowania i grubość pokrywy śnieżnej w Polsce. Acta Agrophysica 19 (3). 501-514.

4. Falarz M., 2007. Potencjalny okres występowania pokrywy śnieżnej w Polsce i jego zmiany w XX wieku. W: Wahania klimatu $\mathrm{w}$ różnych skalach czasowych i przestrzennych. Red. K. Piotrowicz. R. Twardosz. Instytut Geografii i Gospodarki Przestrzennej UJ w Krakowie. 205-213.

5. Filipiak J., 2004. Zmienność temperatury powietrza na Wybrzeżu i Pomorzu w drugiej połowie XX wieku. Monografie IMGW.

6. Górska-Zajączkowska M., Wójtowicz W., 2011. Odzwierciedlenie zmian klimatycznych w przebiegu fenologicznych pór roku w Poznaniu w latach 1958-2009, UMCS, Lublin.

7. Janasz J., 2000. Warunki termiczne i śnieżne zim w Lublinie (1960/61-1994/95). Acta Agrophysica 34. 71-78.

8. Kożuchowski K. (red.), 2004. Skala, uwarunkowania i perspektywy współczesnych zmian klimatycznych w Polsce, Łódź.

9. Kożuchowski K., Żmudzka E., 2001. Ocieplenie w Polsce: skala i rozkład sezonowy zmian temperatury powietrza w drugiej połowie XX wieku. Prz.
Geofiz. 46. 1-2. 81-90.

10. Majewski G., Gołaszewski D., Prezewoźniczuk W., Rozbicki T., 2011. Warunki termiczne i śnieżne zim w Warszawie w latach 1978/79-2009/10. Pr. Stud. Geogr. 47. 147-155.

11. Morawska-Horawska M., 1991. Fale ciepła i chłodu w Krakowie w stuleciu 1881-1980. Wiadomości IMGW.

12. Morrison D.: Wielowymiarowa analiza statystyczna. PWN, Warszawa 1990.,

13. Nowosad M., Bartoszek K., 2007. Wieloletnia zmienność grubości pokrywy śnieżnej w okolicach Lublina. W: Wahania klimatu w różnych skalach czasowych i przestrzennych. Red. K. Piotrowicz. R. Twardosz. Instytut Geografii i Gospodarki Przestrzennej UJ w Krakowie. 411-421.

14. Olba-Zięty E., Grabowski J., 2007. Warunki termiczne i śnieżne zim doliny Biebrzy w latach 1980/19812004/2005. Acta Agrophysica 10 (3). 625-634.

15. Paczos S., 1990. Ekstremalnie ciepłe i chłodne zimy w Polsce w okresie 1951-1990. Mat. Ogólnopolskiej Sesji Naukowej „Meteorologia i hydrologia a ochrona środowiska", Przesieka, PTGeof.

16. Piotrowicz K., 2002-2003. Warunki termiczne zim w Krakowie w latach 1792-2002. Folia Geogr.. Ser. Geogr.-Phys. 33-34. 89-104.

17. Radzka E., 2015. Termiczna zima w środkowowschodniej Polsce Zeszyty Naukowe Ostrołęckiego Towarzystwa Naukowego.

18. Stanisz A.: Przystępny kurs statystyki z zastosowaniem STATISTICA PL na przykładach $\mathrm{z}$ medycyny.T.3. Analizy wielowymiarowe. StatSoft, Kraków 2009.

19. Warakomski W., 1989/90. W poszukiwaniu koncepcji anomalii klimatycznych. Annales UMCS. 